Zeszyty Naukowe Szkoły Głównej Gospodarstwa Wiejskiego

Ekonomika i Organizacja Gospodarki Żywnościowej nr 125 (2019), 59-72

DOI 10.22630/EIOGZ.2019.125.5

Piotr Kułyk ${ }^{\bowtie}$, Mariola Michałowska

Wydział Ekonomii i Zarządzania

Uniwersytet Zielonogórski

\title{
Cena a gotowość do zapłaty za określone produkty ekologiczne na przykładzie mieszkańców województwa lubuskiego
}

\begin{abstract}
Abstrakt. Rozwój rynku żywności ekologicznej nastąpił w wyniku m.in. zwiększającej się świadomości konsumentów na temat zdrowego odżywiania, troski o swoich najbliższych, a także rozprzestrzeniania się informacji o przekroczeniach dotyczących poziomu pestycydów w żywności, norm dioksyn w mięsie i wielu innych toksycznych związków chemicznych. Na uwagę zasługuje również zwiększająca się dostępność żywności ekologicznej. Coraz większa liczba sklepów ma w swojej ofercie asortymentowej żywność pochodzącą z upraw i hodowli ekologicznych, co w efekcie wpływa na zwiększenie popytu na ten rodzaj żywności. Zachowania konsumenta dotyczące produktów ekologicznych są determinowane nie tylko zwiększającą się świadomością ekologiczną, ale zależą od wielu czynników, wśród których istotną rolę odgrywają czynniki ekonomiczne. Poznanie uwarunkowań zakupu ekoproduktów ma kluczowe znaczenie w rozwoju rynku żywności ekologicznej. Celem niniejszego opracowania jest, po pierwsze, zidentyfikowanie czynników determinujących zachowania konsumentów na rynku produktów ekologicznych, ze szczególnym uwzględnieniem ekonomicznych. Po drugie, ustalenie zależności między poziomem przeciętnego miesięcznego dochodu na osobę a liczbą osób w gospodarstwie domowym. Niewątpliwie wyższe ceny produktów ekologicznych w porównaniu z ich odpowiednikami konwencjonalnymi oraz niskie dochody konsumentów ograniczają ich nabywanie. Artykuł zawiera wyniki przeprowadzonego badania ankietowego wśród respondentów w województwie lubuskim. Wyniki badania wskazują, że gotowość do zapłaty wyższej ceny wynika nie tylko z dostrzegalnej jakości produktów, walorów smakowych, składu produktu, stylu życia, czy też walorów zapachowych, ale także z dbałości o stan środowiska naturalnego oraz zdrowie swoje i swoich najbliższych.
\end{abstract}

Słowa kluczowe: produkt ekologiczny, cena, dochody i wydatki gospodarstw domowych, gotowość do zapłaty

Kody JEL: Q11, D11, D12

Piotr Kułyk https://orcid.org/0000-0003-2786-4020; Mariola Michałowska

https://orcid.org/0000-0002-6281-5446

p.kulyk@wez.uz.zgora.pl, UZ, WEiZ, ul. Podgórna 50, 65-246 Zielona Góra 


\section{Wstęp}

Na poziom i strukturę spożycia żywności wpływają uwarunkowania o charakterze makro- i mikroekonomiczny. Wśród uwarunkowań makroekonomicznych wyróżnia się poziom dochodu narodowego, tempo i perspektywy jego zmian, proporcje jego podziału, ceny środków produkcji i dóbr konsumpcji, poziom inflacji i inne. Z kolei uwarunkowania mikro odnoszą się do dochodów osobistych, potrzeb, popytu, czasu wolnego, dostępu oraz prawa i zasad korzystania z dóbr publicznych, efektywności wykorzystania dochodów itp. [Jeżewska-Zychowicz i in. 2009].

Według Ustawy z dnia 9 maja 2014 roku o informowaniu o cenach towarów i usług cena to wartość wyrażona w jednostkach pieniężnych, którą kupujący jest obowiązany zapłacić przedsiębiorcy za towar lub usługę. Ustawa o ochronie konkurencji i konsumentów z dnia 16 lutego 2007 roku rozszerzyła zakres pojęcia ceny o opłaty o charakterze cen, marże handlowe, prowizje i narzuty do cen. Cena reprezentuje wartość dobra lub usługi zarówno dla sprzedawcy, jak i dla nabywcy i jest przedmiotem ich decyzji ekonomicznych [Szumilak 1998, s. 39]. Jak wykazały liczne badania, związek między ceną a produktem polega na tym, że przeważnie konsumenci wiążą wysokie ceny z dobrą jakością i odwrotnie - niskie ceny ze słabą jakością danego produktu [Karasiewicz 1997, s. 28]. Tak więc wysoka cena odpowiada wysokiej jakości produktu, a niska - niskiej jakości. Zdaniem Cz. Bywalca [2009] ceny odgrywają bardzo ważną rolę przy zakupach tzw. dóbr wyższego rzędu, w odniesieniu do artykułów tańszych natomiast rola cen jest niewielka lub też nie mają one żadnego znaczenia. Warto w tym miejscu zauważyć, że poziom oraz relacje cen produktów w ogromnej mierze determinują wielkość i strukturę zakupów w gospodarstwach domowych, a poprzez to kształtują siłę nabywczą ich dochodów [Bywalec 2009, s. 111].

Zachowania konsumentów na rynku żywności zależą od różnych czynników, wśród których można wyróżnić zarówno wewnętrzne, jak i zewnętrzne. Czynniki psychologiczne (motywy zakupu, przekonania, postawy) tworzą wewnętrzne uwarunkowania zachowań konsumentów, a czynniki ekonomiczne (cena produktu, dochody konsumenta) oraz społeczno-kulturowe (stosunek do innych ludzi, przynależność do grup odniesienia, przynależność do klasy społecznej, kultura materialna i duchowa) stanowią uwarunkowania zewnętrzne [Kotler 1999]. Z badań E. Olech i M. Kuboń [2015, s. 169] wynika, że niezależnie od przyjętych kryteriów, najczęstszą przyczyną zakupu produktów ekologicznych było przekonanie klientów o ich właściwościach zdrowotnych, czyli brak konserwantów i sztucznych barwników, a także dbanie o zdrowe odżywianie.

Głównym celem opracowania jest zidentyfikowanie czynników determinujących zachowania konsumentów na rynku produktów ekologicznych, ze szczególnym uwzględnieniem produktów ekonomicznych. Ponadto ustalenie zależności między poziomem przeciętnego miesięcznego dochodu na osobę a liczbą osób 
w gospodarstwie domowym. W opracowaniu poddano weryfikacji następujące hipotezy badawcze:

H1 - występuje zależność wysokości dochodu na osobę od liczby osób w gospodarstwie domowym;

H2 - liczba osób w gospodarstwie domowym ma wpływ na wysokość miesięcznych łącznych wydatków na żywność ekologiczną;

H3 - większość respondentów dokonujących zakupu żywności ekologicznej wykazuje gotowość do płacenia wyższych cen za produkty ekologiczne od produktów konwencjonalnych.

Do realizacji założonego celu wykorzystano badania własne oraz informacje pochodzące ze źródeł wtórnych.

\section{Badania skłonności konsumentów do zapłaty wyższej ceny za żywność ekologiczną w literaturze przedmiotu}

Z przeglądu literatury przedmiotu wynika, że wśród najważniejszych przyczyn ograniczających konsumpcję certyfikowanych produktów ekologicznych jest zbyt wysoka cena. I tak np. badanie OECD [2011, s. 122-124] dotyczące zachowań konsumentów w zakresie żywności ekologicznej ukazuje, że na wzrost zakupu żywności ekologicznej mogłaby wpłynąć niższa cena. Ponad 50\% respondentów deklarowało, że niższa cena zachęcałaby ich do większego spożycia produktów ekologicznych. $\mathrm{Na}$ drugim miejscu pod względem czynników, które mogłyby wpływać na wzrost zakupu produktów pochodzących z upraw ekologicznych, okazało się większe zaufanie do certyfikacji i oznakowania produktów ekologicznych (37\%), kolejno zdrowie (30\%), a także korzyści dla środowiska. Na lepszą dostępność oraz wygląd produktów ekologicznych wskazało $20 \%$ respondentów.

Do podobnych wniosków prowadzą badania B. Vlahović, A. Puškarić i M. Jeločnik [2011, s. 48], którzy zauważyli, że 34\% respondentów przyznaje, że brakuje im zaufania do producentów ekologicznych. Nie wierzą że żywość ta jest produkowana w ramach systemu produkcji ekologicznej. Wśród przyczyn niedokonywania zakupów pojawiają się m.in.: wysoka cena produktów (31\%), niewystarczająca liczba punktów, gdzie można nabyć produkty $(21 \%)$, niedostateczne działania marketingowe producentów (8\%) i inne powody (6\%). Zdaniem P. Kułyka i M. Michałowskej [2018, s. 273] w sytuacji rezygnacji przez konsumentów z produktów ze względu na zbyt wysoką cenę, czy też zmniejszonej dostępności do rynku żywności ekologicznej szczególnego znaczenia nabierają działania marketingowe. W tym przypadku należy szczególnie podkreślać wysoką jakość tych produktów, a także zestaw korzyści, jakie przynosi jej spożywanie [Kułyk i Michałowska 2018, s. 273].

Warto również zauważyć, jak wynika z badań wspominanych autorów, że wśród respondentów, którzy nie kupują produktów pochodzących z upraw ekologicznych 
dominują osoby z niższym poziomem wykształcenia i niskimi dochodami. Tak więc poziom dochodów znacząco ogranicza popyt na te produkty. Wyniki badania pozostają w zgodzie z wynikami C. Leifert i M. Bourlakis [2004, s. 48] wskazującymi wśród powodów zmniejszonego popytu na produkty ekologiczne wysokie ceny $(53 \%)$ oraz wysoki stopień nieufności do tych produktów $(22 \%)$, a także potwierdzają rezultaty uzyskane przez innych badawczy. S. Bonti-Ankomah, E.K. Yiridoe [2006, s. 33] zauważyli, że większość konsumentów nie jest skłonna do zapłacenia wyższej ceny za produkty żywności ekologicznej niż 10-20\% w porównaniu do żywności nieekologicznej. Jednak jak wskazują badania G. Turco [2002, s. 34] konsumenci poszczególnych państw wykazuja gotowość do zapłacenia ceny wyższej nawet od 35 do 100\% (tab. 1). Tak więc skłonność do zapłacenia wyższej ceny za żywność ekologiczną jest zróżnicowana w poszczególnych krajach.

Tabela 1

Skłonność do zapłacenia wyższej ceny za żywność ekologiczna

\begin{tabular}{|c|c|}
\hline Kraj & Skłonność do zapłacenia wyższej ceny za żywność ekologiczna (\%) \\
\hline Australia & $20-40$ \\
\hline Austria & $25-30$ \\
\hline Dania & $20-30$ \\
\hline Francja & $25-30$ \\
\hline Włochy & $35-100$ \\
\hline Niemcy & $20-50$ \\
\hline Holandia & $15-20$ \\
\hline Szwecja & $20-40$ \\
\hline Szwajcaria & $10-40$ \\
\hline Wielka Brytania & $30-50$ \\
\hline Japonia & $10-20$ \\
\hline Stany Zjednoczone & $10-30$ \\
\hline
\end{tabular}

Źródło: [Turco 2002, s. 34].

Na uwagę zasługuje również fakt, że ceny produktów ekologicznych są o wiele wyższe od produktów konwencjonalnych. Jak wynika z raportu Żywność ekologiczna w Polsce 2017 przygotowanego przez firmę IMAS International Sp. z o.o., są one wyższe przeważnie od 50\% wzwyż, ale zdarzają się kategorie produktów droższe o niecałe 20\% [Żywność ekologiczna...2017, s. 13]. Z kolei z badań nad rolnictwem społecznie zrównoważonym wynika, że ceny żywności ekologicznej są o 50-200\% wyższe od cen żywności powstałej metodami konwencjonalnymi [Brzostek-Kasprzak i in. 2013, s. 28]. Reasumując, uzyskane wyniki różnych ich autorów w większości przypadków wskazują istotny wpływ cen na decyzje nabywcze konsumentów na rynku żywności ekologicznej. 


\section{Materiał i metodyka badań}

Badanie empiryczne z wykorzystaniem metody ankietyzacji zostało przeprowadzone od maja do września 2016 roku. Dobór respondentów był losowy z wykorzystaniem metody doboru warstwowego według przedziału wieku. Do określenia liczebności próby zastosowano wzór [Kaczmarczyk 2003]:

$$
n=\frac{u^{2} \cdot p \cdot(1-p)}{e_{p}^{2}}
$$

gdzie:

$n$-wielkość próby,

$u^{2}$ - współczynnik zależny od przyjętego poziomu ufności przy poziomie ufności 0,95 ,

$u=1,96$,

$e_{p}^{2}$ - błąd szacunkowy, przyjmuje się w przedziale od 1-10\%

$p$ - częstotliwość względna (struktury cechy $\mathrm{p}$ ).

Celem obliczenia minimalnej liczebności próby dla konsumentów sporządzono strukturę ludności według wieku w województwie lubuskim, którą ukazano w tabeli 2.

\section{Tabela 2}

Struktura ludności według wieku w województwie lubuskim w 2015 roku

\begin{tabular}{|c|c|c|}
\hline Ludność według wieku (przedział wiekowy) & Liczba osób & $(\%)$ \\
\hline $0-2$ lata & 28762 & 2,83 \\
\hline $3-6$ & 43816 & 4,30 \\
\hline $7-12$ & 62372 & 6,13 \\
\hline $13-15$ & 28845 & 2,83 \\
\hline $16-18$ & 31763 & 3,12 \\
\hline $\mathbf{1 9 - 2 4}$ & 74807 & 7,35 \\
\hline $\mathbf{2 5 - 2 9}$ & 74519 & 7,32 \\
\hline $\mathbf{3 0 - 3 4}$ & 87847 & 8,63 \\
\hline $\mathbf{3 5 - 3 9}$ & 84368 & 8,29 \\
\hline $\mathbf{4 0 - 4 4}$ & 72387 & 7,11 \\
\hline $\mathbf{4 5 - 4 9}$ & 59146 & 5,81 \\
\hline $\mathbf{5 0 - 5 4}$ & 63345 & 6,22 \\
\hline $\mathbf{5 5 - 5 9}$ & 79251 & 7,78 \\
\hline $\mathbf{6 0 - 6 4}$ & 76488 & 7,51 \\
\hline $\mathbf{6 5 - 6 9}$ & 60505 & 5,94 \\
\hline $\mathbf{7 0 - 7 4}$ & 27375 & 2,69 \\
\hline $\mathbf{7 5 - 7 9}$ & 26160 & 2,57 \\
\hline $\mathbf{8 0}$ lat i więcej & 36319 & 3,57 \\
\hline Razem & 1018075 & 100,00 \\
\hline
\end{tabular}

Źródło: Opracowanie na podstawie [Urząd Statystyczny..., 2016, s. 101]. 
Po podstawieniu odpowiednich wartości do wzoru otrzymano:

$$
n=\frac{1,96^{2} \cdot 0,81 \cdot 0,19}{0,05^{2}}
$$

$n=236$ respondentów.

W postępowaniu badawczym ogółem zebrano 541 kwestionariuszy, w tym prawidłowo wypełnionych było 500 i dane liczbowe zawarte w tych kwestionariuszach poddano dalszej analizie (tab. 3).

\section{Tabela 3}

Charakterystyka próby badawczej

\begin{tabular}{|c|c|c|}
\hline \multirow{2}{*}{ Wyszczególnienie } & \multicolumn{2}{|c|}{ Respondenci } \\
\hline & Liczba & $(\%)$ \\
\hline \multicolumn{3}{|c|}{ Płeć } \\
\hline Kobieta & 198 & 66 \\
\hline Mężczyzna & 104 & 34 \\
\hline \multicolumn{3}{|c|}{ Miejsce zamieszkania } \\
\hline Miasto & 191 & 63 \\
\hline Wieś & 111 & 37 \\
\hline \multicolumn{3}{|c|}{ Wykształcenie } \\
\hline Średnie & 97 & 32 \\
\hline Wyższe & 205 & 68 \\
\hline \multicolumn{3}{|c|}{ Przedział wieku } \\
\hline Do 25 lat & 33 & 11 \\
\hline 26-36 lat & 79 & 26 \\
\hline $37-46$ lat & 98 & 32 \\
\hline $47-56$ lat & 56 & 19 \\
\hline Powyżej 56 lat & 36 & 12 \\
\hline \multicolumn{3}{|c|}{ Dochody w przeliczeniu na jedną osobę w gospodarstwie domowym (zł netto) } \\
\hline Poniżej 500 & 2 & 1 \\
\hline $500-1000$ & 49 & 16 \\
\hline $1001-1500$ & 67 & 22 \\
\hline $1501-2000$ & 120 & 40 \\
\hline $2001-2500$ & 43 & 14 \\
\hline 2501-3000 & 0 & 0 \\
\hline $3001-3500$ & 21 & 7 \\
\hline
\end{tabular}

Źródło: Obliczenia własne na podstawie przeprowadzonych badań. 
Wśród 500 osób biorących udział w badaniu 198 respondentów, tj. około 40\% w ogóle nie dokonywało zakupów żywności ekologicznej, w tym 119 kobiet (ponad 60\%) i 79 mężczyzn (około 40\%). Jak się okazuje, jednym z najbardziej istotnych powodów niedokonywania zakupów żywności ekologicznej jest zbyt wysoka cena tych produktów. Innymi powodami były m.in.: bariery związane z dostępnością do żywności ekologicznej spowodowane brakiem sklepu z żywnością ekologiczną w pobliżu miejsca swojego zamieszkania, czy trudności w jej nabyciu.

Struktura badanej grupy dokonującej zakupów żywności ekologicznej kształtowała się następująco: wśród 302 respondentów 66\% stanowiły kobiety, a 34\% mężczyźni (tab. 3). Biorąc pod uwagę miejsce zamieszkania, 63\% respondentów było mieszkańcami miasta, a pozostali zamieszkiwali wieś. W strukturze badanej grupy wyróżniono pięć przedziałów wieku. Wśród respondentów przeważały osoby z wykształceniem wyższym (68\%). Odsetek respondentów z wykształceniem średnim stanowił 32\%. W badanej grupie największy odsetek respondentów (40\%) deklarował dochód miesięczny przypadający średnio na 1 osobę w gospodarstwie domowych w przedziale 1501-2000 zł. Najmniejszy zaś poniżej 500 zł (1\%). Z kolei $22 \%$ badanych wskazało na dochód miesięczny przypadający średnio na 1 osobę w przedziale 1001-1500 zł, a 16\% w przedziale 500-1000 zł. Co siódmy badany wskazywał na dochód mieszczący się w przedziale 2001-2500 zł na 1 osobę, a co czternasty badany na przedział 3001-3500 zł.

\section{Wyniki badań}

W tabeli 4 zawarto wysokość dochodów na 1 członka gospodarstwa domowego oraz liczbę osób w gospodarstwie. Na podstawie analizy średnich warunkowych oraz przy wykorzystaniu stosunku korelacyjnego zbadano, czy w badanej grupie osób występuje zależność dochodu na osobę od liczby osób w gospodarstwie domowym.

Wyznaczono średnie warunkowe cechy zależnej w czterech kategoriach wielkości gospodarstw:

$$
\begin{aligned}
& \bar{y}_{1-2}=1980,83 \mathrm{zl} \\
& \bar{y}_{3-4}=1836,97 \mathrm{zł} \\
& \bar{y}_{5-6}=1073,21 \mathrm{zl} \\
& \bar{y}_{\text {pow.6 }}=750 \mathrm{zł}
\end{aligned}
$$

Średni dochód na 1 osobę we wszystkich gospodarstwach domowych wyznaczono według wzoru [Bobowski 2004, s. 83]:

$$
y=\frac{\sum \bar{y}_{i} \cdot n i}{N}=1642,80 \mathrm{zl}
$$


Tabela 4

Gospodarstwa domowe według dochodów na 1 osobę w zł oraz liczba osób w gospodarstwie

\begin{tabular}{|c|c|c|c|c|c|}
\hline \multirow{2}{*}{$\begin{array}{c}\text { Dochód netto } \\
\text { na } 1 \text { osobę } \\
\text { w zł (Y) }\end{array}$} & \multicolumn{4}{|c|}{ Liczba osób w gospodarstwie $(X)$} & \multirow{2}{*}{$n_{i}$} \\
\hline & $1-2$ & $3-4$ & $5-6$ & pow.6 & \\
\hline Poniżej 500 & 0 & 0 & 0 & 2 & 2 \\
\hline $500-1000$ & 1 & 0 & 20 & 28 & 49 \\
\hline $1001-1500$ & 31 & 9 & 25 & 2 & 67 \\
\hline $1501-2000$ & 25 & 92 & 3 & 0 & 120 \\
\hline $2001-2500$ & 11 & 32 & 0 & 0 & 43 \\
\hline $2501-3000$ & 0 & 0 & 0 & 0 & 0 \\
\hline $3001-3500$ & 21 & 0 & 0 & 0 & 21 \\
\hline ni & 89 & 133 & 48 & 32 & 302 \\
\hline
\end{tabular}

Źródło: Obliczenia własne na podstawie przeprowadzonych badań.

Na podstawie analizy średnich warunkowych cechy zależnej stanowiącej średnie dochody na osobę w wyodrębnionych czterech kategoriach wielkości gospodarstw można stwierdzić, że występuje zależność dochodów na 1 osobę od liczby osób w gospodarstwie domowym, gdyż średnie warunkowe są zróżnicowane. Ponadto występuje ujemna zależność wysokości dochodów od liczby osób, ponieważ wraz ze wzrostem liczby osób w gospodarstwie maleje średnia wysokość dochodu na 1 osobę.

Celem sprawdzenia, czy w badanej zbiorowości występuje zależność wysokości dochodu na osobę od liczby osób w gospodarstwie domowym, dokonano pomiaru natężenia zależności wykorzystując stosunek korelacyjny. Obliczenia zawarto w tabeli 5.

Dla oceny natężenia zależności wykorzystano stosunek korelacyjny o postaci [Bobowski 2004, s. 81]:

$$
r^{k}=\frac{s\left(\bar{y}_{x j}\right)}{s(y)}=\frac{\sqrt{\frac{\sum_{j}\left(y_{x j}-\bar{y}\right)^{2} \cdot n_{j}}{N}}}{\sqrt{\frac{\sum_{i}\left(y_{i}-\bar{y}\right)^{2} \cdot n_{i}}{N}}}=0,68
$$

Otrzymana wartość oznacza silną zależność.

Celem sprawdzenia, czy istnieje wyraźny związek między wielkością miesięcznych wydatków na żywność ekologiczną a liczbą osób w gospodarstwie domowym ukazano korelację dwóch cech (tab. 6). W tym celu wykorzystano statystykę chi-kwadrat, a do oceny siły zależności między tymi cechami współczynnik korelacji Pearsona. 


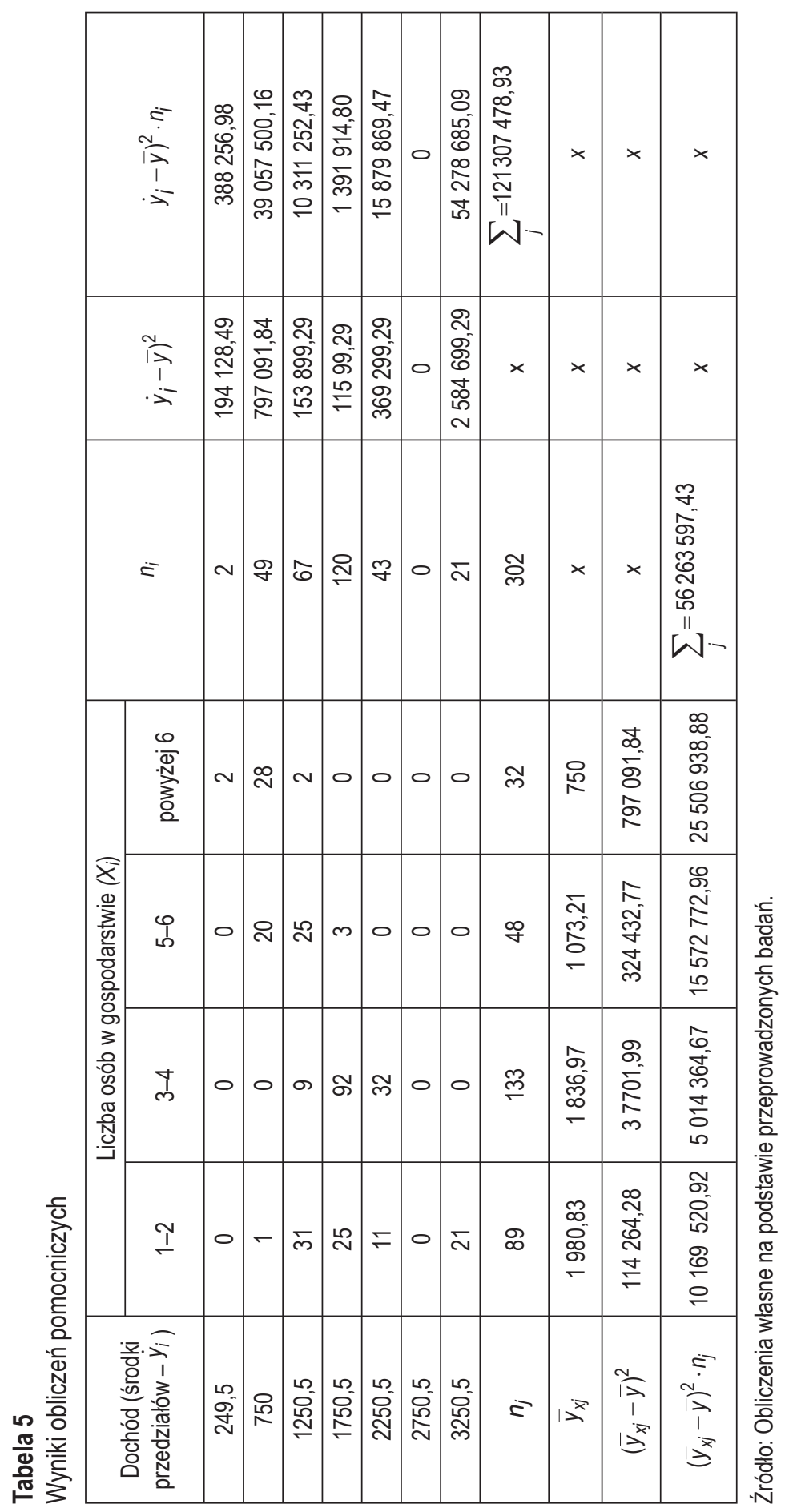




\section{Tabela 6}

Gospodarstwa domowe województwa lubuskiego według liczby osób oraz wysokość miesięcznych wydatków na żywność ekologiczną

\begin{tabular}{|c|c|c|c|c|c|}
\hline \multirow{2}{*}{ Wydatki w zł (Y) } & \multicolumn{4}{|c|}{ Liczba osób w gospodarstwie $(X)$} & \multirow{2}{*}{$n_{i}$} \\
\hline & $1-2$ & $3-4$ & $5-6$ & powyżej 6 & \\
\hline poniżej 100 & 19 & 14 & 0 & 7 & 40 \\
\hline $100-300$ & 22 & 23 & 22 & 16 & 83 \\
\hline $301-500$ & 31 & 56 & 19 & 9 & 115 \\
\hline $501-700$ & 17 & 40 & 7 & 0 & 64 \\
\hline$n_{i}$ & 89 & 133 & 48 & 32 & 302 \\
\hline
\end{tabular}

Źródło: Obliczenia własne na podstawie przeprowadzonych badań.

Wartość statystyki $\chi^{2}=38,59 . \mathrm{Z}$ rozkładu chi-kwadrat, przy poziomie istotności $\alpha=0,05$ i $(\mathrm{r}-1)(\mathrm{k}-1)=6$ stopniach swobody otrzymano wartość 12,5916 , a ponieważ $\chi^{2}$ jest większa od wartości krytycznej, zachodzi więc istotna zależność między badanymi cechami. Celem obliczenia siły związku między zmiennymi posłużono się współczynnikiem kontyngencji Pearsona. Wartość współczynnika Pearsona wynosząca 0,34 wskazuje na umiarkowaną zależność. Można zatem wnioskować, że liczba osób w gospodarstwie domowym ma wpływ na wysokość miesięcznych wydatków na żywność ekologiczną.

Respondentów postanowiono również zapytać, czy planują w najbliższych pięciu latach zwiększyć wydatki na żywność ekologiczną (rys. 1).

\section{Rysunek 1}

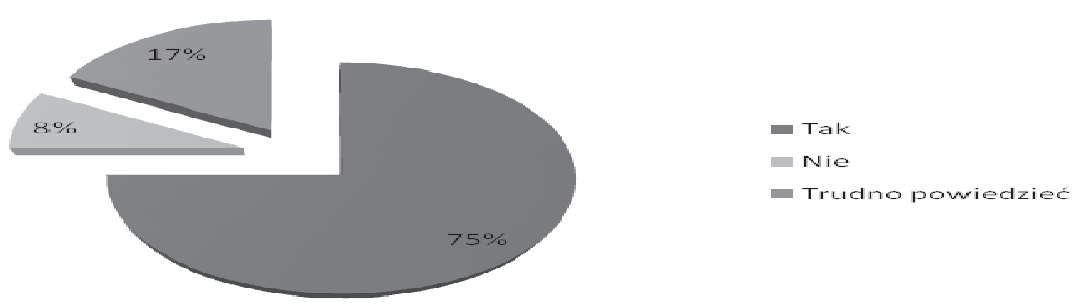

Planowane zwiększenie wydatków na produkt ekologiczny w ciagu najbliższych pięciu lat Źródło: Opracowanie własne na podstawie przeprowadzonych badań.

Jak się okazuje, 75\% respondentów potwierdziło, że planuje zwiększyć wydatki na żywność ekologiczną w ciagu najbliższych pięciu lat. Innego zdania było 8\% badanych, a 17\% odpowiedziało ,trudno powiedzieć”.

Analizując dane dotyczące skłonności do poniesienia przez respondentów wyższych kosztów związanych z zakupem żywności ekologicznej w porównaniu do żywności wytwarzanej metodami konwencjonalnymi, można zauważyć, że 62\% respondentów jest skłonnych wydać więcej na produkt ekologiczny. Pozostali respondenci nie są w stanie ponieść większych kosztów na zakup produktu o potwierdzonej ekologicznej jakości produktu (rys. 2). 


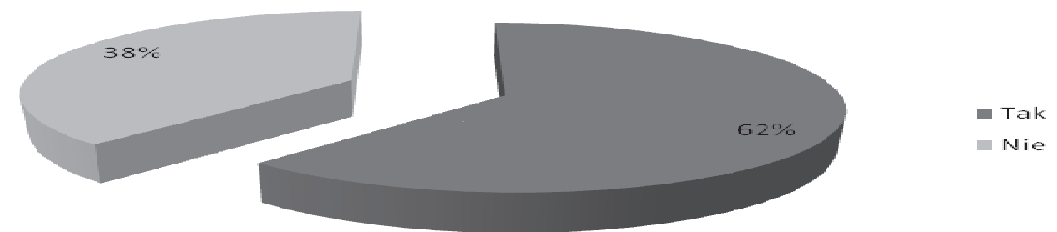

\section{Rysunek 2}

Skłonność respondentów do zapłacenia wyższej ceny w związu z zakupem produktu ekologicznego w porównaniu z produktem konwencjonalnym $(n=302)$

Źródło: Opracowanie własne na podstawie przeprowadzonych badań.

Spośród 302 respondentów 187 osób deklarowało skłonność do zapłacenia wyższej ceny w związku z zakupem produktu ekologicznego od ich konwencjonalnego odpowiednika. Wśród 187 respondentów 55\% wyraża gotowość do zapłacenia ceny wyższej od 5 do $10 \%$, a $41 \%$ od 21 do $25 \%$, a pozostali w przedziale 41 do $45 \%$ (rys. 3).

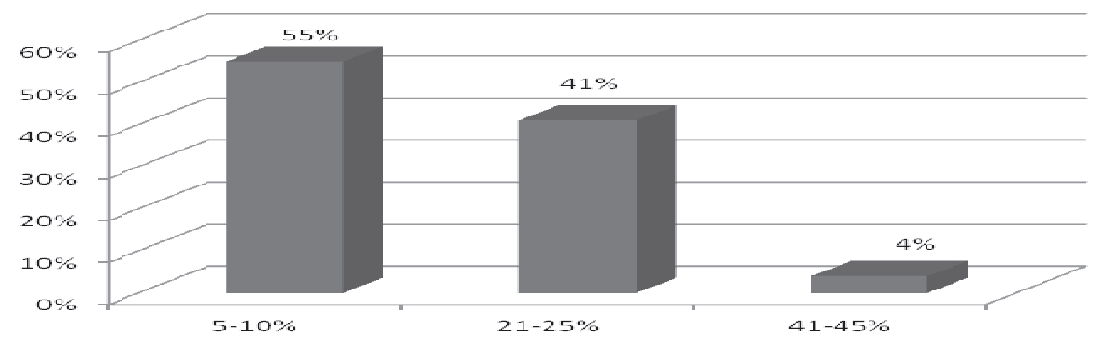

\section{Rysunek 3}

Deklarowana skłonność do zapłacenia wyższej ceny za produkt ekologiczny w porównaniu do konwencjonalnego $(n=187)$

Źródło: Opracowanie własne na podstawie przeprowadzonych badań.

Jak się okazuje, 38\% badanych nie jest w ogóle skłonnych do zapłacenia wyższej ceny za żywność pochodzącą z upraw ekologicznych od produktów konwencjonalnych. Z kolei osoby (102), które deklarują gotowość do zapłacenia wyższej ceny, są skłonne ponieść wydatek większy o 5-10\%. Tylko niewielki odsetek osób (4\%) jest skłonny zaakceptować cenę wyższą mieszczącą się w przedziale $41-45 \%$. Tym samym pozostaje to $\mathrm{w}$ zgodzie $\mathrm{z}$ początkowymi wynikami badań wskazującymi cenę jako barierę ograniczająca popyt na rynku żywności ekologicznej.

Pytając respondentów o czynniki decydujące o nabywaniu żywności ekologicznej, można stwierdzić, że najważniejszym czynnikiem jest ich jakość (liczba wskazań - 298). Na drugim miejscu uplasowały się walory smakowe (liczba wskazań 232), a na trzecim skład i styl życia (odpowiednio po 211 wskazań). Wśród innych czynników pojawiły się również m.in. walory zapachowe, ale także dbałość o stan środowiska naturalnego oraz zdrowie swoje i swoich najbliższych. 


\section{Podsumowanie}

Reasumując, nie ulega wątpliwości, że na decyzje nabywcze konsumentów istotny wpływ ma cena. Wyniki przeprowadzonego badania wskazują na silną zależność między zmiennymi takimi jak wysokość dochodu na osobę a liczba osób w gospodarstwie, a także istotną między wielkością miesięcznych łącznych wydatków na żywność ekologiczną a liczbą osób w gospodarstwie domowym. Warto w tym miejscu zauważyć, że wartość współczynnika Pearsona wskazała na istnienie umiarkowanej zależności między wielkością miesięcznych łącznych wydatków na żywność ekologiczną a liczbą osób w gospodarstwie domowym. Ponadto większość osób (187) dokonujących zakupu żywności ekologicznej wykazuje gotowość do zapłacenia wyższej ceny za produkt pochodzący z upraw ekologicznych od ceny za ich konwencjonalny odpowiednik. Spośród tej grupy osób 55\% respondentów biorących udział w badaniu wyraża gotowość do zapłacenia ceny wyższej od 5 do $10 \%$. Z analizy materiału empirycznego wynika również, że większość badanych planuje zwiększyć wydatki na żywność ekologiczną w ciagu najbliższych pięciu lat, a najważniejszym czynnikiem decydującym o nabywaniu produktów ekologicznych jest ich jakość.

Z przeglądu badań własnych i innych autorów wynika, że wśród przyczyn niedokonywania zakupów pojawiają się najczęściej: wysoka cena produktów, niewystarczająca liczba punktów, gdzie można nabyć produkty. Warto również zauważyć, że respondentom brakuje zaufania do producentów ekologicznych.

Wnioski z zaprezentowanych badań skłaniają do poszukiwania rozwiązań w kierunku działań marketingowych opartych na ekologicznej jakości produktu, ze szczególnym uwzględnieniu właściwej komunikacji i budowania atmosfery zaufania.

\section{Podziękowania}

Zrealizowano przy pomocy finansowej Miasta Zielona Góra.

\section{Literatura}

BOBOWSKI Z., 2014: Wybrane metody statystyki opisowej i wnioskowania statystycznego, Wałbrzyska Wyższa Szkoła Zarządzania i Przedsiębiorczości, Wałbrzych.

BONTI-ANKOMAH S., YIRIDOE E.K., 2006: Organic and Conventional Food: A Literature Review of the Economics of Consumer Perceptions and Preferences. Final Report, Organic Agriculture Centre of Canada Nova Scotia Agricultural College, Canada, pobrano z: http://www.organicagcentre.ca/Docs/BONTI\%20\%26\%20YIRIDOE\%20April \%2028\%202006\%20Final.pdf [dostęp: 15.07.2018]. 
BRZOSTEK-KASPRZAK B., KWASEK M., OBIEDZIŃSKA A., OBIEDZIŃSKI M.W., 2013: Z badań nad rolnictwem społecznie zrównoważonym (21). Żywność ekologicz$n a$ - regulacje prawne, system kontroli i certyfikacji, w Kwasek M. (red. nauk.) Instytut Ekonomiki Rolnictwa i Gospodarki Żywnościowej Państwowy Instytut Badawczy, Warszawa.

BYWALEC CZ., 2009: Ekonomika i finanse gospodarstw domowych, Wydawnictwo Naukowe PWN, Warszawa.

JEŻEWSKA-ZYCHOWICZ M., BABICZ-ZIELIŃSKA E., LASKOWSKI W., 2009: Konsument na rynku nowej żywności, Wydawnictwo SGGW, Warszawa.

KACZMARCZYK S., 2003: Badania marketingowe, metody i techniki, PWE, Warszawa.

KARASIEWICZ G., 1997: Marketingowe strategie cen, PWE, Warszawa.

KOTLER PH., 1999: Marketing. Analiza, planowanie, wdrażanie i kontrola, Wydawnictwo FELBERG SJA, Warszawa.

KUŁYK P., MICHAŁOWSKA M., 2018: Regional Conditions of the Ecological Goods Market, Handel Wewnętrzny 3, 265-276.

LEIFERT C., BOURLAKIS M., 2004: Recent Developments in the EU Organic Food Market, Acorn Conference, 26th March, Cornwall near Charlottetown, Canada, pobrano z: http://oacc.info/DOCs/Carlo\%20Liefert\%20Organic\%20Food\%20Markets.pdf, [za:] Vlahović B., Puškarić A., Jeločnik M., 2011: Consumer Attitude to Organic Food Consumption in Serbia, Economic Sciences Series, 63, 1.

OECD 2011: Greening Household Behaviour. The Role of Public Policy, OECD Publishing.

OLECH E., KUBOŃ M., 2015: Motywy wyboru produktów ekologicznych przez konsumentów segmentu demograficznego z terenu Małopolski, Roczniki Naukowe Stowarzyszenia Ekonomistów Rolnictwa i Agrobiznesu 17(1), 164-169.

SZUMILAK J. 1998: Cena, [w:] J. Altkorn, T. Kramer (red.), Leksykon marketingu, PWE, Warszawa.

TURCO G., 2002: Organic Food - An Opportunity, at Who's Expense? Industry Note. Food and Agribusiness Research, Rabobank International, Sydney. www.rabobank.com/attachments/in-043-2002, [za:] Bonti-Ankomah S., Yiridoe E.K., 2006: Organic and Conventional Food: A Literature Review of the Economics of Consumer Perceptions and Preferences. Final Report, Organic Agriculture Centre of Canada Nova Scotia Agricultural College, Canada;

US, 2016: Rocznik statystyczny województwa lubuskiego, Urząd Statystyczny w Zielonej Górze 2016.

Ustawa z dnia 16 lutego 2007 r. o ochronie konkurencji i konsumentów, Dz.U. z 2007 r. Nr 50, poz. 331 .

Ustawa z dnia 9 maja 2014 r. o informowaniu o cenach towarów i ustug, Dz.U z 2014, poz. 915.

VLAHOVIĆ B., PUŠKARIĆ A., JELOČNIK M., 2011: Consumer Attitude to Organic Food Consumption in Serbia, Economic Sciences Series, 63(1), 45-52.

Żywność ekologiczna w Polsce 2017, IMAS International Sp. z o.o., pobrano z: http:// imas. pl/wp-content/uploads/2017/10/3402_raport_10.2017.pdf [dostęp: 15.07.2018]. 


\title{
Price and readiness to pay for specific ecological products on the example of the inhabitants of the Lubuskie Voivodeship
}

\begin{abstract}
The development of the organic food market has resulted from, among others, an increasing consumer awareness of healthy eating, caring for their loved ones, as well as the spread of information on exceedances regarding the level of pesticides in food, standards of dioxins in meat and many other toxic chemicals. Noteworthy is also the increasing availability of organic food. An increasing number of stores have in their range of products food from organic farming, which in effect affects the increase in demand for this type of food. Consumer behaviour regarding organic products is determined not only by increasing ecological awareness, but depends on many factors, among which economic factors play an important role. Understanding the conditions of purchasing ecoproducts is crucial in the development of the organic food market. The aim of this study is, firstly, to identify the factors determining consumer behaviour on the market of organic products, with particular emphasis on economic factors. Secondly, establishing the relationship between the level of average monthly income per person and the number of people in the household. Undoubtedly, higher prices of organic products compared to their conventional counterparts and low income of consumers limit their purchase. The article contains the results of a survey carried out among respondents in the Lubuskie Voivodeship. The results of the study show that the higher willingness to pay results not only from the perceived quality of products, taste values, product composition, lifestyle, or fragrance values, but also from care for the natural environment and the health of both themselves and their relatives.
\end{abstract}

Key words: green products, price, household income and expenditure of households, readiness to pay

JEL Classification: Q11, D11, D12

Otrzymano: 15 listopada 2018 / Zaakceptowano: 03 stycznia 2019

Received: 15 November 2018 / Accepted: 03 January 2019 